\title{
A MECENAS DE JAMES JOYCE
}

\section{DIRCE WALTRICK DO AMARANTE $e$ SÉRGIO MEDEIROS}

A tímida Harriet Shaw Weaver (1876-1961), então com 37 anos e envolvida com literatura em língua inglesa, foi uma das responsáveis pela publicação, em 1913, na ousada revista The Egoist, de episódios do romance Retrato do artista quando jovem (1916), de James Joyce (18821941), pagando-lhe 50 libras pelo uso de "seu maravilhoso livro". Quando Joyce lhe perguntou, tempos depois, se ela não teria um pouco de sangue irlandês, a editora de The Egoist respondeu: "Receio ser irremediavelmente inglesa". Embora tivesse aderido ao feminismo e depois ao comunismo, a srta. Weaver era, nas palavras de Virginia Woolf, uma mulher antiquada nos modos e nos trajes, em aparente contradição com suas convicções de vanguarda. Enquanto procurava um editor na Inglaterra para o romance Ulisses, a srta. Weaver visitou Leonard e Virginia Woolf, com a esperança de que a Hogarth Press, que ambos haviam fundado recentemente, o publicasse. No seu diário, a romancista destacou a aparência incongruente da srta. Weaver, descrevendo-a como uma missionária toda abotoada de luvas de lã cuja causa era um livro "carregado de indecências".

Aos poucos a srta. Weaver foi se revelando como mais do que somente uma boa "missionária". Por meio de seus advogados, destinou anonimamente a Joyce 200 libras, como doação espontânea, as quais deveriam lhe ser entregues em quatro parcelas. Joyce conjecturou inicialmente que o seu benfeitor pudesse ser um homem, conforme deixou expresso na carta que lhe enviou, datada de 6 de março de 1917. Essa carta está traduzida na íntegra abaixo, e nela se verifica a ojeriza habitual de Joyce a usar vírgulas, a par da franqueza e da espontaneidade que dão ao leitor a impressão de que foi escrita de um jato e não passou por correções. O mesmo estilo reaparece na segunda carta traduzida, datada de 20 de julho de 1919, quando a identidade da misteriosa benfeitora havia enfim se revelado. Inicialmente, foram os advogados da 
srta. Weaver que entraram em contato com o escritor, então residindo em Zurique. Na segunda carta, escrita dois anos depois da primeira, Joyce reclama do desinteresse desses mesmos advogados, mas nesse ponto da correspondência o leitor deparará com um desabafo que não lhe permitirá uma verdadeira compreensão de toda a situação a que se refere Joyce num tom lamuriento. O que fica claro, nessa segunda carta, é que a srta. Weaver não respondeu bem ao episódio Sereias. Na biografia de Joyce escrita por Richard Ellmann[1] lemos o que ela disse por carta ao autor de Ulisses: “O sr. Pound me enviou o episódio Sereias há pouco tempo. Penso poder ver que seu texto tem sido até certo ponto afetado por suas preocupações; quero dizer que o episódio não me parece atingir a culminância habitual de intensidade". Mas essa opinião morna de maneira nenhuma significou, como chegou a temer Joyce, uma diminuição do empenho de sua benfeitora em facilitar a sua vida em todos os sentidos possíveis. A respeito de outro episódio do romance, que lhe foi enviado depois, a opinião da srta. Weaver foi, desta vez, muita entusiasmada, e ela ainda alertou Joyce em nova carta: "Preciso pedir-lhe mais uma vez que não preste a menor atenção a qualquer comentário tolo que eu possa fazer - que realmente devo deixar de fazer, se puder".

Ao chamá-la de "mulher extraordinária”, Richard Ellmann afirma que a "generosidade da srta. Weaver continuou pelo resto da vida de Joyce, e mesmo depois, pois ela pagou por seu funeral." Quando Joyce escrevia Finnegans Wake, para garantir a calma necessária para finalizar essa obra capital, não teve escolha senão enviar a Londres a sua filha Lucia Joyce, que sofria de sério desequilíbrio mental. A srta. Weaver a hospedou em casa, apesar de seu comportamento imprevisível (Lucia a via ora como amiga, ora como uma carcereira[2]), e, como aconteceu em outras vezes, fez esse favor ao grande romancista sem nenhuma exigência, pois não esperava dele recompensas: desejava apenas que ele finalizasse a sua obra.

As cartas de Joyce para Harriet Shaw Weaver estão dispersas nos três volumes do livro Letters of James Joyce (Nova York: The Viking Press, 1957-1966) e num volume mais recente, Selected letters of James Joyce (Nova York: The Viking Press, 1975), que é uma seleção do conteúdo dos três outros com alguns acréscimos, todos editados por Richard Ellmann. 


\begin{tabular}{l|l|l|}
\hline celeuma & número 4 | maio $2014 \quad 109$ \\
\hline
\end{tabular}

A primeira carta aqui traduzida, que foi a primeira enviada por Joyce à sua "secreta benfeitora", só consta de Selected letters of James Joyce.

Também a segunda carta que traduzimos, embora apareça no primeiro volume de Letters of James Joyce, está ali incompleta; a versão completa integra somente o volume de 1975. Essa carta, numa versão incompleta, aparece na tradução brasileira da biografia James Joyce, de Richard Ellmann.

[1] RICHARD ELLMANN. James Joyce. São Paulo, Globo, 1989. (Também consultamos: RICHARD ELLMANN. James Joyce. Nova Yorl, Londres e Toronto, Oxford University Press, 1965.)

[2] CAROL LOEB SHLOSS. Lucia Joyce: to dance in the Wake. New York, Farrar, Straus and Giroux, 2003.

DIRCE WALTRICK DO AMARANTE e SÉRGIO MEDEIROS, ambos professores da Universidade Federal de Santa Catarina (UFSC), organizaram e traduziram Cartas a Nora, de James Joyce (Iluminuras, 2012), finalista do Prêmio Jabuti em 2013 na categoria Tradução. Preparam no momento a edição em português, a sair pela Iluminuras, das cartas que James Joyce escreveu para Harriet Weaver. 